\title{
The switch from buprenorphine to tapentadol: is it worth?
}

\author{
Adriana Miclescu
}

Department of Anaesthesia and Intensive Care, Uppsala University Hospital, Sweden

\begin{abstract}
Opioid analgesia continues to be the primary pharmacologic intervention for managing acute pain and malignant pain in both hospitalized and ambulatory patients. The increasing use of opioids in chronic nonmalignant pain is more problematic. Opioid treatment is complicated with the risks raised by adverse effects, especially cognitive disturbance, respiratory depression but also the risk of tolerance, opioid abuse and drug-disease interactions. Despite the growing number of available opioids within the last years, adequate trials of opioid rotation are lacking and most of the information is anecdotal. This article reviews the clinical evidence surrounding the switch from transdermal buprenorphine to tapentadol in malignant and non-malignant pain. Tapentadol acts on both the $\mu$-opioid receptors (MOR) and on the neuronal reuptake of noradrenaline with a limited usefulness in acute pain management while buprenorphine is a mixed agonistantagonist, and both present some advantages over other opioids. Both drugs show particular pharmacodynamic and pharmacokinetic properties which reduce the risks of development of tolerance, opioid abuse, diversion and determine fewer hormone changes than the "classical opioids" making these opioids more attractive than other opioids in long term opioid treatment. However, in the absence of powered clinical trials, the evidence to support the method used for transdermal buprenorphine rotation to tapentadol is weak.
\end{abstract}

Keywords: chronic pain, tapentadol, buprenorphine, opioid tolerance, opioid rotation

Rom J Anaesth Int Care 2016; 23: 133-139

\section{Introduction}

Opioid analgesia continues to be the primary pharmacologic intervention for managing postoperative pain and cancer pain. The increasing use of opioids in chronic non-malignant pain has become more problematic. Opioid treatment is complicated by the risks raised by adverse effects, especially cognitive disturbances, respiratory depression but also the risk of tolerance, opioid abuse and drug-disease interactions. If an opioid causes severe adverse effects or fails to provide analgesia, one of the common procedures is to

Adress for correspondence:

Adriana Miclescu, MD PhD, DEAA

Associate Professor

Multidisciplinary Pain Clinic

Uppsala University Hospital

SE-751 85 Sweden

E-mail: adriana.miclescu@akademiska.se decrease the dose, to taper the opioid and to replace it with another opioid. Opioid rotation has been defined as a strategy applied during opioid therapy for pain that refers to a switch from one opioid to another in an effort to improve therapeutic response, clinical outcomes and to reduce undesirable effects $[1,2]$. Despite the growing number of available opioids within the last years, the appropriate trials of opioid rotation are few and there is insufficient clinical evidence to support the selection of one opioid over another when the need for opioid rotation arises [3-5]. This article reviews the clinical evidence surrounding the switch between buprenorphine and tapentadol.

\section{Pharmacological aspects of tapentadol}

Tapentadol is a centrally acting analgesic that binds to $\mu$-opioid receptor (MOR), $\delta$-opioid receptor (DOR), $\kappa$-opioid receptor (KOR) and an inhibitor of norepinephrine (NE) reuptake. It was developed to exploit a synergistic interaction between opioids and the NE 
system [6-8]. The combined mechanism of action was expected to improve the therapeutic usefulness of opioid analgesics, particularly in the treatment of neuropathic pain conditions as demonstrated in animal $[9,10]$ and human studies [11-14]. By adding the noradrenergic mechanism of action it was intended not only to increase the analgesic effect of tapentadol but also to produce an opioid-sparing effect and to reduce the risk of opioid induced side effects [6]. Agonists of the $\mu$ opioid receptors differ in their intrinsic activity (amount of receptor occupancy to induce a determined level of response) $[15,16]$. The degree of tolerance has been found to vary with the intrinsic activity and is inversely related to the reserve of spare opioid receptors [17]. A low intrinsic efficacy agonist such as morphine has high occupancy characteristics and may induce tolerance more readily than a high intrinsic efficacy agonist [18]. The intrinsic activity of tapentadol at the $\mu$ receptor showed a greater receptor reserve that lies between that of buprenorphine, oxycodone and morphine potentially explaining the favorable profile of side effects related to $\mu$ receptors and tolerance development [19]. Tapentadol follows a linear pharmacokinetics model. Oral absorption is rapid, with Cmax typically reached in $\leq 2$ hours and has a $T_{1 / 2}$ of about 4 hours. No active metabolites were identified that contributed to tapentadol's analgesic properties and it is primarily excreted through the kidney within 4 hours [20]. For this reason, tapentadol should be administrated with caution in patients with severely impaired renal function [21].

The US Food and Drug Administration approved tapentadol extended-release in November of 2008 for the management of acute moderate to severe pain in adults and in August 2012 for the treatment of pain in diabetic neuropathy. At the time of writing this article, despite a high Number Needed to Treat $(\mathrm{NNT}=10 \cdot 2)$ and an inconclusive recommendation for the treatment of neuropathic pain in adults according to Grading of Recommendations Assessment, Development, and Evaluation (GRADE), tapentadol is widely used [22]. Examining the abuse potential, it was found that tapentadol was less likely to be abused than most other Schedule II analgesics examined [22, 23]. Tapentadol is considered to have a reduced doctor shopping risk (obtaining prescriptions from multiple prescribers) and lower abuse and diversion risk than oxycodone, but similar in these aspects to tramadol [24].

\section{Pharmacological aspects of buprenorphine}

Buprenorphine possesses also a unique and complex pharmacology, acting as an agonist at $\mu$-opioid receptor (MOR), $\delta$-opioid receptors (DOR), ORL-1 (NOP) receptors and as an antagonist at the $\kappa$-opioid receptor
(KOR) [25]. The ability of the drug to interact with the ORL-1 receptor leads to "counter-opioid actions in the brain" [26]. Buprenorphine's effect on the ORL1 opioid receptor dampens the brain reward system and that implies less tolerance and less reward which is responsible for the beneficial effects of buprenorphine in the treatment of opioid abuse $[25,26]$. Buprenorphine was long thought to have a bell-shaped or inverted U-shaped dose-response curve [27, 28] which postulated that the agonist effects increase linearly with increasing doses of the drug until it reaches a plateau and no longer continue to increase with further increase in doses (ceiling effect) limiting its effect as a strong analgesic. The above dose-response curve was observed in rodents and not in humans [26]. Butler has addressed these false beliefs related with the bellshaped curve, the plateau dose-response curve in a recent review [25]. Buprenorphine is a lipophilic molecule and distributes well in tissues including the brain [29]. Despite this it takes a long time after entering the CNS for buprenorphine to occupy receptors in brain tissue [29]. Thus, the onset time to effect and offset time are both prolonged (Table 1) reducing its usefulness for acute pain. Buprenorphine is metabolized in the liver through Cyp3A4 mediated N-dealkylation [30]. The metabolites of buprenorphine are excreted through the liver and there is no accumulation of drug or metabolites in those with renal failure, even when they have no renal function [31]. There is some evidence that activation of ORL-1 has effects in neuropathic pain and offers a distinct benefit [32].

The pharmacological aspects presented previously demonstrate a possible superiority of tapentadol and buprenorphine over other opioids in safety and reducing the intensity of side effects especially tolerance development and abuse potential compared to full agonist opioids [33, 34].

\section{Opioid rotation-genetic considerations}

Opioid rotation is based, in part, on the clinical observation that the response to different opioids in terms of analgesia and adverse effects vary markedly in a single individual [35]. There is also a great variation in the response between different individuals. The variation in human response to different opioids "could be explained by genetic variation in metabolizing enzymes and transporters mediating opioid pharmacokinetics" as well as by genetic variation in the pattern of opioid receptor subtypes in the brain and spinal cord and signal transduction elements mediating pharmacodynamics $[35,36]$. Another aspect that justifies the need of opioid rotation after a drug has been administrated for a time is the development of tolerance $[35,37]$ and elimination of toxic opioid metabolites specific to the initial anal- 
Table 1. Characteristics of tapentadol and buprenorphine

\begin{tabular}{|c|c|c|}
\hline Properties & Tapentadol & Buprenorphine \\
\hline \multicolumn{3}{|l|}{ Skeletal formula } \\
\hline Receptor binding & $\begin{array}{l}\text { Agonist on } \mu \text { receptor (MOR) } \\
\text { Noradrenaline reuptake inhibitor }\end{array}$ & $\begin{array}{l}\text { Antagonist on } \mu \text { receptors (MOR), } \delta \text {-opioid receptors (DOR), } \\
\text { ORL-1 (NOP) receptors, } \kappa \text { (agonist, weak partial) (KOR) }\end{array}$ \\
\hline Routes of administration & Oral & Transdermal, transmucosal, IV, IM \\
\hline Metabolic pathway & $\begin{array}{l}\text { Glucuronidation CYP2C9 (minor) CYP2C19 } \\
\text { (minor), CYP2D6 (minor) }\end{array}$ & CYP3A4, glucuronidation \\
\hline Ceiling dose & $600 \mathrm{mg} /$ day & Yes \\
\hline Onset of effect & $\begin{array}{l}\text { Slow } \\
\text { Analgesia occurs in } 32 \mathrm{~min}\end{array}$ & $\begin{array}{l}\text { Slow } \\
\text { I.v. onset } 10-30 \mathrm{~min}\end{array}$ \\
\hline Time to Peak effect & $\leq 2$ hours & I.v. $70-100 \mathrm{~min}$ \\
\hline Duration of effect & $\begin{array}{l}\text { Extended release } \mathrm{T} 1 / 24 \mathrm{~h} \\
\text { Immediate release }\end{array}$ & $\begin{array}{l}\text { I.v. long } 6-8 \mathrm{~h} \\
\text { Sublingual } 20 \mathrm{~h} \\
\text { Transdermal } 73 \mathrm{~h}\end{array}$ \\
\hline Biological half time & 4 hours & $20-70 \mathrm{hrs}$, mean 37 hours \\
\hline Bioavailability & Orally $32 \%$ [38] & $\begin{array}{l}\text { I.m. } 70 \% \\
\text { Sublingual solution } 49 \% \text { [39] } \\
\text { Sublingual tablet } 29 \% \\
\text { Intranasal } 48 \% \text { [40] }\end{array}$ \\
\hline Protein binding & $20 \%$ & $96 \%$ \\
\hline Excretion & Urine and faeces $(1 \%)$ & Biliary and renal \\
\hline
\end{tabular}

gesic [18]. Opioid switch requires a clearer understanding of the genetic factors contributing to the individual response to opioids in order to predict the outcome of opioid rotation in different individuals. The $\mu$-opioid receptor gene encoded by the genetic locus OPRM1 is the primary binding site for endogenous opioid peptides and opioid analgesics [41]. A number of nonsynonymous allelic variants of OPRM1 have been identified within the population [42] that may contribute to individual variations in response to opioid analgesics.

Knapman et al. [43] demonstrated that buprenorphine signalling to several effectors via the N40D variant of MOR receptors ( $\mu$-opioid receptor) is impaired, and this may have important consequences in a clinical setting for individuals carrying the N40D allele. The N40D variant is the most common MOR receptor variant present in $10-50 \%$ of the population [44] and could be responsible for genetical variations of the patients who do not respond to buprenorphine therapy and need opioid rotation in order to achieve significantly better pain control.

The studies regarding genetical variation of tapentadol are non-existent and the differences in treatment variations between individuals remains to be investigated. In one study tapentadol demonstrated in vitro a pattern distinct from classical MOR agonists. It shares with fentanyl the ability to induce a MOR up-regulation and with morphine the ability to induce nociceptin/ orphaninFQ (NOP, ORL-1) receptor down-regulation and has the inability to induce internalization [45].
A long-term exposure to one drug often results in the development of tolerance to the effects of other structurally similar drugs in the same pharmacologic class (cross-tolerance). Each opioid receptor is functionally sub-classified into different opioid receptor subtypes, although, specific genes corresponding to each of these receptor subtypes is still unidentified [46]. When one opioid is substituted for another, the secondary opioid may bind to a different receptor subtype than the initial compound (incomplete cross tolerance), thereby limiting the apparent extent of cross-tolerance $[47,48]$. Anecdotally, clinicians have long observed the benefits of switching from one opioid to another without knowing that the improvement of analgesia and decreasing tolerance is based on incomplete cross tolerance. Despite the fact that incomplete cross tolerance was demonstrated mostly in MOR receptors, theoretically it is possible that it occurs with other opioid receptors, explaining the possibility to switch between tapentadol and buprenorphine and obtain good clinical results.

\section{Opioid switch and semi switch of transdermal buprenorphine to tapentadol prolonged release - practical considerations}

The general indications for opioid switching in acute units were insufficient analgesia in $43 \%$, intolerable side effects in $20 \%$ of the patients [49]. Patients with 
cancer receiving opioids required opioid rotation in a proportion of $21-44 \%$ [50]. Opioid switch has been demonstrated to be an effective method to improve analgesia and reduce side effects in more than $80 \%$ of cancer patients with a poor response to an opioid [51]. In patients with chronic pain, achieving significantly better pain control was probably the most frequent reason for switching from one opioid to tapentadol $(91.1 \%)$. Other indications for opioid switching to tapentadol were insufficient quality of life $(70.3 \%)$ and tolerability (31.9\%) [52]. Unfortunately, the economic considerations and the absence of well controlled studies are the main reasons for not having tapentadol as the first choice for opioid rotation. According to our protocols, tapentadol is used after "classical" opioids [53]. However, in clinical practice there are some situations where opioid rotation from buprenorphine transdermal to tapentadol may be indicated.

Buprenorphine transdermal (TDB) is available in Sweden as seven day, low dose patches (Norspan ${ }^{\circledR}$ BuTrans ${ }^{\circledR}$ delivering 5, 10, 15, 20, $30 \mu \mathrm{g} / \mathrm{h}$ ). TDB has a good level of evidence and is relatively safe and well tolerated in both cancer [54] and non-cancer pain [55, $56]$ as a step 2 analgesic in the WHO ladder. TDB is unsuitable for patients with unstable pain who require rapid changes in dosage, so it is unsuitable for the acute treatment of pain or for patients with severe cancer pain who require step 3 opioids according to the WHO ladder. Because TDB is a low dose preparation, the first method to control pain after trying maximum TDB dose escalation would be a rescue analgesia with a short-acting normal-release opioid given as required. Sublingual forms of buprenorphine (Temgesic ${ }^{\circledR}$ delivering $0.2 \mathrm{mg}$ or $0.4 \mathrm{mg}$ ) have been used for some time for this purpose. Combinations of immediate release full $\mu$-agonists, such as short acting morphine, ketobemidone, oxycodone for treatment of breakthrough pain and a basal analgesic regime of transdermal buprenorphine shows an additive analgesic effect and has been used as an effective and safe treatment $[29,57]$. Difficulty to control pain with TDB and with short acting opioids represents an indication for opioid rotation to other long-acting opioids. The doses needed for tapentadol follow previous general recommendations for opioids: in the case of sufficient analgesia on TDB, a tapentadol dose should be introduced at an equianalgesic dose of $50-75 \%$; in the case of insufficient analgesia with TDB with or without short acting opioids, and the equianalgesic dose of the new drug it needs to be $75-100 \%$. TDB is not available in higher doses than $30 \mu \mathrm{g} / \mathrm{h}$ and this is one of the main reasons that in clinical practice in Sweden one rarely observes dose escalations of TDB to more than $40-60 \mu \mathrm{g} / \mathrm{h}$. Buprenorphine tablets are an increasing problem in
Sweden and in other countries such as Finland and Malaysia because buprenorphine is the first choice drug for abuse [58]. In that respect opioid dose escalation with intolerable and unmanageable side effects, such as somnolence or mental clouding is not often seen in adults with TDB. Cognitive disturbances represent an indication for opioid rotation. Both tapentadol [59] and buprenorphine [60] have a lower impact on sex hormone concentrations than pure opioid analgesics. The pharmacological aspects presented in the beginning of this article demonstrate a possible superiority of tapentadol and buprenorphine in terms of lower tolerance development, less abuse and diversion potential than other strong opioids [19, 61-63]. For this reason TDB rotation to tapentadol may be attractive to patients with chronic pain and the need for long time treatment with opioids. There may be benefit in a switch to a different route of administration when the patients react unfovarably to TDB (skin allergic reactions because of buprenorphine patch or when patients have difficulties with patch adhesion). The change of TDB to tapentadol in the case of progressive renal insufficiency is not recommended. In some patients, in whom other treatment options including opioid rotation were not effective, partial rotation (semiswitch) using same dose TDB and adding tapentadol prolonged release may be another strategy of improving analgesia.

Future studies need to confirm the benefits of combination therapy and the role of opioid rotation between buprenorphine and tapentadol.

\section{Conclusion}

Theoretically, the unique pharmacodynamic and pharmacokinetic properties of both buprenorphine and tapentadol with a reduced risk of development of tolerance, opioid abuse, diversion and fewer hormone changes than the "classical opioids" make these opioids more attractive than other opioids in long term opioid treatment. However, in the absence of powered clinical trials, the evidence to support the method used for transdermal buprenorphine rotation to tapentadol is weak.

\section{Conflict of interest}

Nothing to declare

\section{References}

1. Fine PG, Portenoy RK, Chou R, Cruciani RA, Gordon D, Inturrisi $\mathrm{CE}$, et al. Establishing "best practices" for opioid rotation: conclusions of an expert panel. J Pain Symptom Manage 2009; 38:418-425. DOI: 10.1016/j.jpainsymman.2009.06.002

2. Knotkova H, Fine PG, Portenoy RK. Opioid rotation: the science and the limitations of the equianalgesic dose table. J Pain 
Symptom Manage 2009; 38: 426-439. DOI: 10.1016/ j.jpainsymman.2009.06.001

3. Quigley C. Opioid switching to improve pain relief and drug tolerability. Cochrane Database Syst Rev 2004; (3): CD004847. DOI: $10.1002 / 14651858$.CD004847

4. Vissers KC, Besse K, Hans G, Devulder J, Morlion B. Opioid rotation in the management of chronic pain: where is the evidence? Pain Pract 2010; 10: 85-93. DOI: 10.1111/j.1533-2500. 2009.00335.x

5. Smith HS, Peppin JF. Toward a systematic approach to opioid rotation. J Pain Res 2014; 7: 589-608. DOI: 10.2147/JPR. S55782

6. Tzschentke TM, De Vry J, Terlinden R. Tapentadol hydrochloride: Analgesic mu-opioid receptor agonist noradrenaline reuptake inhibitor. Drugs Future 2006; 31: 1053-1061

7. Raffa RB, Buschmann H, Christoph T, Eichenbaum G, Englberger $\mathrm{W}$, Flores $\mathrm{CM}$, et al. Mechanistic and functional differentiation of tapentadol and tramadol. Expert Opin Pharmacother 2012; 13: 1437-1449. DOI: $10.1517 / 14656566.2012 .696097$

8. Hartrick CT, Rodríguez Hernandez JR. Tapentadol for pain: a treatment evaluation. Expert Opin Pharmacother 2012; 13: 283-286. DOI: $10.1517 / 14656566.2012 .648616$

9. Schröder W, De Vry J, Tzschentke TM, Jahnel U, Christoph T. Differential contribution of opioid and noradrenergic mechanisms of tapentadol in rat models of nociceptive and neuropathic pain. Eur J Pain 2010; 14: 814-821. DOI: 10.1016/ j.ejpain.2010.05.005

10. Cristoph T, De Vry J, Tzschentke TM. Tapentadol, but not morphine, selectively inhibits disease-related thermal hyperalgesia in a mouse model of diabetic neuropathic pain. Neurosci Lett 2010; 470: 91-94. DOI: 10.1016/j.neulet.2009.12.020

11. Schwartz S, Etropolski M, Shapiro DY, Okamoto A, Lange R, Haeussler J, et al. Safety and efficacy of tapentadol ER in patients with painful diabetic peripheral neuropathy: results of a randomized-withdrawal, placebo-controlled trial. Curr Med Res Opin 2011; 27: 151-162. DOI: 10.1185/03007995.2010. 537589

12. Vinik AI, Shapiro DY, Rauschkolb C, Lange B, Karcher K, Pennett D, et al. A randomized withdrawal, placebo-controlled study evaluating the efficacy and tolerability of tapentadol extended release in patients with chronic painful diabetic peripheral neuropathy. Diabetes Care 2014; 37: 2302-2309. DOI: $10.2337 / \mathrm{dc} 13-2291$

13. Schwartz S, Etropolski MS, Shapiro DY, Rauschkolb C, Vinik AI, Lange $\mathrm{B}$, et al. A pooled analysis evaluating the efficacy and tolerability of tapentadol extended release for chronic, painful diabetic peripheral neuropathy. Clin Drug Investig 2015; 35 : 95-108. DOI: $10.1007 / \mathrm{s} 40261-014-0249-3$

14. Vadivelu N, Kai A, Maslin B, Kodumudi G, Legler A, Berger JM. Tapentadol extended release in the management of peripheral diabetic neuropathic pain. Ther Clin Risk Manag 2015; 11: 95 105. DOI: $10.2147 /$ TCRM.S32193

15. Adams JU, Paronis CA, Holtzman SG. Assessment of relative intrinsic activity of mu-opioid analgesics in vivo by using betafunaltrexamine. J Pharmacol Exp Ther 1990; 255: 1027-1032

16. Zimmerman DM, Leander JD, Reel JK, Hynes MD. Use of betafunaltrexamine to determine mu opioid receptor involvement in the analgesic activity of various opioid ligands. J Pharmacol Exp Ther 1987; 241: 374-378

17. Duttaroy A, Yoburn BC. The effect of intrinsic efficacy on opioid tolerance. Anesthesiology 1995; 82: 1226-1236
18. Mercadante S, Portenoy RK. Opioid poorly-responsive cancer pain. Part 2: basic mechanisms that could shift dose response for analgesia. J Pain Symptom Manage 2001; 21: 255-264

19. Sadeghi M, Tzschentke T, Christie MJ. $\mu$-Opioid receptor activation and noradrenaline transport inhibition by tapentadol in rat single locus coeruleus neurons. Br J Pharmacol 2015; 172: 460-468. DOI: $10.1111 / \mathrm{bph} .12566$

20. Wade W, Spruill W. Tapentadol hydrochloride: a centrally acting oral analgesic. Clin Ther 2009; 31: 2804-2818. DOI: 10.1016/ j.clinthera.2009.12.003

21. Smith H, Bruckenthal P. Implications of opioid analgesia for medically complicated patients. Drugs Aging 2010; 27: 417433. DOI: $10.2165 / 11536540-000000000-00000$

22. Finnerup N, Attal N, Haroutounian S, McNicol E, Baron R, Dworkin RH, et al. Pharmacotherapy for neuropathic pain in adults: a systematic review and meta-analysis. Lancet Neurol 2015; 14: 162-173. DOI: 10.1016/S1474-4422(14)70251-0

23. Butler SF, McNaughton EC, Black RA. Tapentadol abuse potential: a postmarketing evaluation using a sample of individuals evaluated for substance abuse treatment. Pain Med 2015; 16: 119-130. DOI: 10.1111/pme.12524

24. Schug SA, Goddard C. Recent advances in the pharmacological management of acute and chronic pain. Ann Palliat Med 2014; 3: 263-275. DOI: 10.3978/j.issn.2224-5820.2014.10.02

25. Butler S. Buprenorphine - Clinically useful but often misunderstood. Scand J Pain 2013; 4: 148-152. DOI: http://dx.doi.org/ 10.1016/j.sjpain.2013.05.004

26. Lutfy K, Cowan A. Buprenorphine: a unique drug with complex pharmacology. Curr Neuropharmacol 2004; 2: 395-402. DOI: $10.2174 / 1570159043359477$

27. Dum JE, Herz A. In vivo receptor binding of the opiate partial agonist, buprenorphine, correlated with its agonistic and antagonistic actions. Br J Pharmacol 1981; 74: 627-633. DOI:10.1111/ j.1476-5381.1981.tb10473.x

28. Lizasoain I, Leza JC, Lorenzo P. Buprenorphine: bell-shaped dose-response curve for its antagonist effects. Gen Pharmacol 1991; 22: 297-300

29. Khanna IK, Pillarisetti S. Buprenorphine - an attractive opioid with underutilized potential in treatment of chronic pain. J Pain Res 2015; 8: 859-870. DOI: 10.2147/JPR.S85951

30. Kobayashi K, Yamamoto T, Chiba K, Tani M, Shimada N, Ishizaki T, Kuroiwa Y. Human buprenorphine N-dealkylation is catalyzed by cytochrome P450 3A4. Drug Metab Dispos 1998; 26: $818-821$

31. Filitz J, Griessinger N, Sittl R, Likar R, Schüttler J, Koppert W. Effects of intermittent hemodialysis on buprenorphine and norbuprenorphine plasma concentrations in chronic pain patients treated with transdermal buprenorphine. Eur J Pain 2006; 10 : 743-748. DOI: 10.1016/j.ejpain.2005.12.001

32. Pergolizzi J, Böger RH, Budd K, Dahan A, Erdine S, Hans G, et al. Opioids and the management of chronic severe pain in the elderly: consensus statement of an International Expert Panel with focus on the six clinically most often used World Health Organization Step III opioids (buprenorphine, fentanyl, hydromorphone, methadone, morphine, oxycodone). Pain Pract 2008; 8: 287-313. DOI: $10.1111 / \mathrm{j} .1533-2500.2008 .00204 . x$

33. Davis MP. Twelve reasons for considering buprenorphine as a frontline analgesic in the management of pain. J Support Oncol 2012; 10: 209-219. DOI: 10.1016/j.suponc.2012.05.002

34. Knezevic NN, Tverdohleb T, Knezevic I, Candido KD. Unique pharmacology of tapentadol for treating acute and chronic pain. 
Expert Opin Drug Metab Toxicol 2015; 11: 1475-1492. DOI: $10.1517 / 17425255.2015 .1072169$

35. Pasternak GW. Molecular biology of opioid analgesia. J Pain Symptom Manage 2005; 29(5 Suppl): S2-S9. DOI: 10.1016/ j.jpainsymman.2005.01.011

36. Yiannakopoulou E. Pharmacogenomics and Opioid Analgesics: Clinical Implications. Int J Genomics 2015; 2015: 368979. DOI: $10.1155 / 2015 / 368979$

37. Riley J, Ross JR, Rutter D, Wells AU, Goller K, du Bois R, et al. No pain relief from morphine? Individual variation in sensitivity to morphine and the need to switch to an alternative opioid in cancer patients. Support Care Cancer 2006; 14: 56-64. DOI: 10.1007/s00520-005-0843-2

38. Fidman B, Nogid A. Role of tapentadol immediate release (Nucynta) in the management of moderate-to-severe pain. PT 2010; 35: 330-357

39. Mendelson J, Upton RA, Everhart ET, Jacob P $3^{\text {rd }}$, Jones RT. Bioavailability of sublingual buprenorphine. J Clin Pharmacol 1997; 37: 31-37

40. Eriksen J, Jensen NH, Kamp-Jensen M, Bjarnø H, Friis P, Brewster D. The systemic availability of buprenorphine administered by nasal spray. J Pharm Pharmacol 1989; 41: 803-805

41. Kleine-Brueggeney M, Musshoff F, Stuber F, Stamer UM. Pharmacogenetics in palliative care. Forensic Sci Int 2010; 203: 63-70. DOI: 10.1016/j.forsciint.2010.07.003

42. Lötsch J, Geisslinger G. Are $\mu$-opioid receptor polymorphisms important for clinical opioid therapy? Trends Mol Med 2005; 11: 82-89. DOI: 10.1016/j.molmed.2004.12.006

43. Knapman A, Santiago M, Connor M. Buprenorphine signalling is compromised at the $\mathrm{N} 40 \mathrm{D}$ polymorphism of the human $\mu$ opioid receptor in vitro. Br J Pharmacol 2014; 171: 42734288. DOI: $10.1111 / \mathrm{bph} .12785$

44. Mura E, Govoni S, Racchi M, Carossa V, Ranzani GN, Allegri M, et al. Consequences of the $118 \mathrm{~A}>\mathrm{G}$ polymorphism in the OPRM1 gene: translation from bench to bedside? J Pain Res 2013; 6: 331-353. DOI: 10.2147/JPR.S42040

45. Caputi FF, Carretta, Tzschentke TM, Candeletti S, Romualdi P. Opioid receptor gene expression in human neuroblastoma SHSY5Y cells following tapentadol exposure. J Mol Neurosci 2014; 53: 669-676. DOI: $10.1007 / \mathrm{s} 12031-014-0235-5$

46. Pasternak GW. Incomplete cross tolerance and multiple mu opioid peptide receptors. Trends Pharmacol Sci 2001; 22: 6770

47. Pasternak GW. Multiple opiate receptors: déjà vu all over again. Neuropharmacology 2004; 47(Suppl 1): 312-323. DOI: 10.1016/j.neuropharm.2004.07.004

48. Drewes AM, Jensen RD, Nielsen LM, Droney J, Christrup LL, Arendt-Nielsen L, et al. Differences between opioids: pharmacological, experimental, clinical and economical perspectives. $\mathrm{Br}$ J Clin Pharmacol 2013; 75: 60-78. DOI: 10.1111/j.13652125.2012.04317.x

49. Kloke M, Rapp M, Bosse B, Kloke O. Toxicity and/or insufficient analgesia by opioid therapy: risk factors and the impact of changing the opioid. A retrospective analysis of 273 patients observed at a single center. Support Care Cancer 2000; 8: 479486

50. Mercadante S, Bruera E. Opioid switching in cancer pain: From the beginning to nowadays. Crit Rev Oncol Hematol 2016; 99: 241-248. DOI: $10.1016 /$ j.critrevonc.2015.12.011

51. Mercadante S, Ferrera P, Villari P, Casuccio A, Intravaia G, Mangione S. Frequency, indications, outcomes, and predictive factors of opioid switching in an acute palliative care unit. J Pain Symptom Manage 2009; 37: 632-641. DOI: 10.1016/ j.jpainsymman.2007.12.024

52. Schwittay A, Schumann C, Litzenburger BC, Schwenke K. Tapentadol prolonged release for severe chronic pain: results of a noninterventional study involving general practitioners and internists. J Pain Palliat Care Pharmacother 2013; 27: 225234. DOI: $10.3109 / 15360288.2013 .816406$

53. Landstinget i Uppsala län. Rekommenderade läkemedel för vuxna 2016-2017 [online]. 2016 [cited 2016, July 31], p 56-63. Available from: http://www.lul.se/Global/Extran\%C3\%A4t/ V\%C3\%A5rdgivare/L\%C3\%A4kemedelsenheten/Dokument/ Reklistan/Rek-lista_vuxna_2016-2017_web.pdf

54. Poulain P, Denier W, Douma J, Hoerauf K, Samija M, Sopata M, et al. Efficacy and safety of transdermal buprenorphine: a randomized, placebo-controlled trial in 289 patients with severe cancer pain. J Pain Symptom Manage 2008; 36: 117-125. DOI: 10.1016/j.jpainsymman.2007.09.011

55. Likar R, Kayser H, Sittl R. Long-term management of chronic pain with transdermal buprenorphine: a multicenter, open-label, follow-up study in patients from three short-term clinical trials. Clin Ther 2006; 28: 943-952. DOI: 10.1016/j.clinthera. 2006.06.012

56. Serpell M, Tripathi S, Scherzinger S, Rojas-Farreras S, Oksche A, Wilson M. Assessment of Transdermal Buprenorphine Patches for the Treatment of Chronic Pain in a UK Observational Study. Patient 2016; 9: 35-46. DOI: 10.1007/ s40271-015-0151-y

57. Mercadante S, Villari P, Ferrera P, Porzio G, Aielli F, Verna L, et al. Safety and effectiveness of intravenous morphine for episodic breakthrough pain in patients receiving transdermal buprenorphine. J Pain Symptom Manage 2006; 32: 175-179. DOI: $10.1016 /$ j.jpainsymman.2006.01.013

58. Zaveri NT. The nociceptin/orphanin FQ receptor (NOP) as a target for drug abuse medications. Curr Top Med Chem 2011; 11: 1151-1156. DOI: $10.2174 / 156802611795371341$

59. Eichenbaum G, Göhler K, Etropolski M, Steigerwald I, Pergolizzi $\mathrm{J}$, Kim M, et al. Does tapentadol affect sex hormone concentrations differently from morphine and oxycodone? An initial assessment and possible implications for opioid-induced androgen deficiency. J Opioid Manag 2015; 11: 211-227. DOI: 10.5055/ jom.2015.0270

60. Hallinan R, Byrne A, Agho K, McMahon CG, Tynan P, Attia J. Hypogonadism in men receiving methadone and buprenorphine maintenance treatment. Int J Androl 2009; 32: 131-139. DOI: $10.1111 /$ j. $1365-2605.2007 .00824 . x$

61. Sittl R, Nuijten M, Nautrup BP. Changes in the prescribed daily doses of transdermal fentanyl and transdermal buprenorphine during treatment of patients with cancer and noncancer pain in Germany: results of a retrospective cohort study. Clin Ther 2005; 27: 1022-1031. DOI: 10.1016/j.clinthera.2005.06.024

62. Sittl R, Nuijten M, Nautrup BP. Patterns of dosage changes with transdermal buprenorphine and transdermal fentanyl for the treatment of noncancer and cancer pain: a retrospective data analysis in Germany. Clin Ther 2006; 28: 1144-1154. DOI: $10.1016 / \mathrm{j}$.clinthera.2006.08.002

63. Muriel C, Failde I, Micó JA, Neira M, Sánchez-Magro I. Effectiveness and tolerability of the buprenorphine transdermal system in patients with moderate to severe chronic pain: a multicenter, open-label, uncontrolled, prospective, observational clinical study. Clin Ther 2005; 27: 451-462. DOI: 10.1016/ j.clinthera.2005.04.007 


\section{Merită să facem trecerea de la buprenorfină la tapentadol?}

\section{Rezumat}

Analgezia bazată pe opioide continuă să reprezinte principala intervenție farmacologică în tratamentul durerii acute şi a celei neoplazice atât în cazul pacienților spitalizați, cât şi în ambulator. Utilizarea crescândă a opioidelor în cazul pacienților cu durere cronică nonneoplazică a devenit problematică. Tratamentul cu opioide se complică prin prezența riscurilor efectelor adverse, în special al disfuncției cognitive, depresiei respiratorii, dar şi de riscul tolerantei, abuzului și interacțiunilor medicamentoase. În ciuda creşterii numărului de opioide din ultimii ani, lipsesc studiile despre rotația acestora, iar informația existentă este neştiințifică. Acest articol face o trecere în revistă a dovezilor clinice care se referă la rotația de la buprenorfina cu absorbție transdermică la tapentadol în durerea canceroasă şi noncanceroasă. Tapentadolul acționează atât pe receptorii $\mu$ de opioide (MOR) cât şi asupra recaptării neuronale de noradrenalină cu acțiune limitată în tratamentul durerii acute, iar buprenorfina este un agonist-antagonist, ambele preparate prezentând o serie de avantaje asupra celorlalte opioide. Ambele posedă caracteristici farmacodinamice și farmacocinetice care reduc riscul dezvoltării toleranței, a abuzului de opioide, diversiunii şi determină mai puține modificări hormonale raportat la „opioidele clasice”, devenind mai atractive pentru tratamentul de lungă durată cu această clasă de preparate. $\mathrm{Cu}$ toate acestea, în absența studiilor $\mathrm{cu}$ putere statistică, dovezile care susțin trecerea de la buprenorfina transdermică la tapantadol sunt insuficiente.

Cuvinte cheie: durere cronică, tapentadol, buprenorfină, toleranță la opioide, rotație opioide 